\title{
Water quality in a pipe distribution network: a case study of a communal water distribution network in Ibadan, Nigeria
}

\author{
M. S. Awopetu ${ }^{1}$, A. O. Coker $^{2}$, J. O. Aribisala ${ }^{1} \&$ S. O. Awopetu ${ }^{3}$ \\ ${ }^{1}$ Department of Civil Engineering, Ekiti State University, \\ Ado- Ekiti, Nigeria \\ ${ }^{2}$ Department of Civil Engineering, University of Ibadan, Nigeria \\ ${ }^{3}$ Nigeria Petroleum Development Company Ltd. (A subsidiary of NNPC), \\ GRA Benin City, Edo State, Nigeria
}

\begin{abstract}
The study identified the levels of pollution such as turbidity, chloride, silica, solids and E-coli in potable water at the point of treatment in Eleyele treatment plant and at various points in the consumer premises, some distance away from the treatment plant to ascertain the quality of water in the pipe distribution network within Ibadan city. Water samples were collected at eleven different locations and subjected to physical, chemical and bacteriological tests and analyses. The results showed that the physical and chemical quality of Eleyele water works compete favourably with international standards such as those of the World Health Organization (WHO) but the bacteriological quality was suspect. Deterioration in water quality with respect to bacteriological quality in the distribution network could be as a result of pipe rust, and old age, leading to constant pipe leakages and burst wherein the E-coli contaminated water infiltrated into the pipe distribution network. In order to avoid E-coli contamination, the study recommends that maintenance of water pipe distribution networks should be planned, implemented and controlled at the same optimum level and operation as for the treatment facilities and the protection of the water source in order to meet international standards.
\end{abstract}

Keywords: water quality, water distribution, pipe network, maintenance, standard. 


\section{Introduction}

The quality of drinking-water is an important environmental determinant of health. Drinking-water quality management continues to be the foundation for the prevention and control of waterborne diseases. Water is essential for life, but it can and does transmit disease in countries in all continents - from the poorest to the wealthiest. The most predominant waterborne disease, diarrhoea, has an estimated annual incidence of 4.6 billion episodes and causes 2.2 million deaths every year $[1,2]$. Consumption of water contaminated by disease-causing agents (pathogens) or toxic chemicals can cause health problems such as diarrhoea, cholera, typhoid, dysentery, cancer and skin diseases [2].

A major objective in water supply quality control work is to reduce the incidence of water-related diseases. This objective depends on the ability to develop water sources to provide an ample supply of wholesome quality, that is, free from visible suspended matters, excessive colour, taste and odour, objectionable dissolved matter, aggressive constituents' bacteria indicative of faecal pollution. The importance of quality changes in distribution is based upon evidence concerning the frequency and extent of known quality changes and their impact upon human health. Thus, for example, a significant proportion of recognized piped drinking water-related disease outbreaks are related to quality deterioration [3, 4]. Drinking water supply must obviously be fit for human consumption, that is, of potable quality and they should be palatable, that is, aesthetically attractive. In addition, as far as is feasible, public water supplies should be suitable for other domestic uses such as cloth washing etc.

Having provided water of suitable quality and quantity by source development process, it becomes necessary to convey the supply to consumers via a distribution system comprising water mains, pumping stations and service reservoirs. Water companies do their utmost to produce drinking water of impeccable quality at treatment plants. The objective of the distribution network is to fulfil the legal obligation to bring this water to the customers in sufficient quantities under sufficient pressure. Next to this quantitative goal, the qualitative goal of the distribution of potable water is to preserve the impeccable quality during the travel time through the network. More realistically the goal is to control deterioration of quality to meet the standards for consumption. When working on community water supply projects it is vital to keep an eye on water quality and identify any microbiological contamination or toxins that may pose a threat to public health [5].

Most domestic and industrial potable water supplies are deteriorated in quality before getting to the consumer premises either as a result of bacteria and other pollutants introduced directly into the network from the treatment plant or from bacteria growing on the pipe walls which are later released into the flowing water by shear loss or by erosion and other pollutants through pipe breakages or joint leakages [6]. However, high bacteria population in potable water network distribution systems sometimes referred to as events or blooms have troubled utilities because of their implications for the hygienic safety, taste and odour of their product [7]. 
Sometimes, the level of pollution in pipe borne water could be so high that it is not advisable to drink water directly from tap. This argument can be substantiated by using glass cup to collect water from tap and allow it to settle for at least ten minutes. It may be discovered that there would be settlement at the bottom and sometimes the wall of the glass cup. The main objective of the study is to identify level of pollutant in already treated (potable) water at the point of distribution in the treatment plant and also at various points in the consumer's premises some distance away from the treatment plant.

\section{Method}

\subsection{Setting}

This research work is carried out on the distribution pipe network of Eleyele treatment plants. Samples (water) were collected at eleven different points or location covering the entire area of Eleyele water works. The authors have adopted the setting mainly to investigate the potability of the potable water coming out of pipes that were laid in 1939, and have exceeded their design period of thirty (30) years.

\subsection{Sampling}

Samples of water for analysis were taken with the great precaution of care. The water was taken from tap across the service area and the control sample was drawn from the treatment plant. Each sample was collected in a white 2 liters airtight container. The sample to be collected was used to rinse the container twice after the water from the tap has been allowed to run for some time. A space for air was left under the cover. The water taken were immediately covered, labeled and sent to the laboratory due notice being previously given in order that they may be dealt with without delay.

\subsection{Research instruments}

The instruments for this study were a number of physical, chemical and bacteriological tests carried out on the water sample collected and this was used to ascertain the level of purity of potable water in the pipe distribution network. The tests carried out are as follows: (i) colour determination using DR 2010 spectrophotometer machine; (ii) turbidity using 6035 Turbid meter machine; (iii) $\mathrm{pH}$ determination using Suntex $\mathrm{pH}$ meter model SP-701; (iv) hardness using ethlenediaminetetraacetic acid (EDTA) titrmetric method; (v) calcium using EDTA titrimetric method; (vi) chloride using argentometric method; (vii) total dissolve solids using CCO 150 conductivity meter machine and (viii) coliform count. 


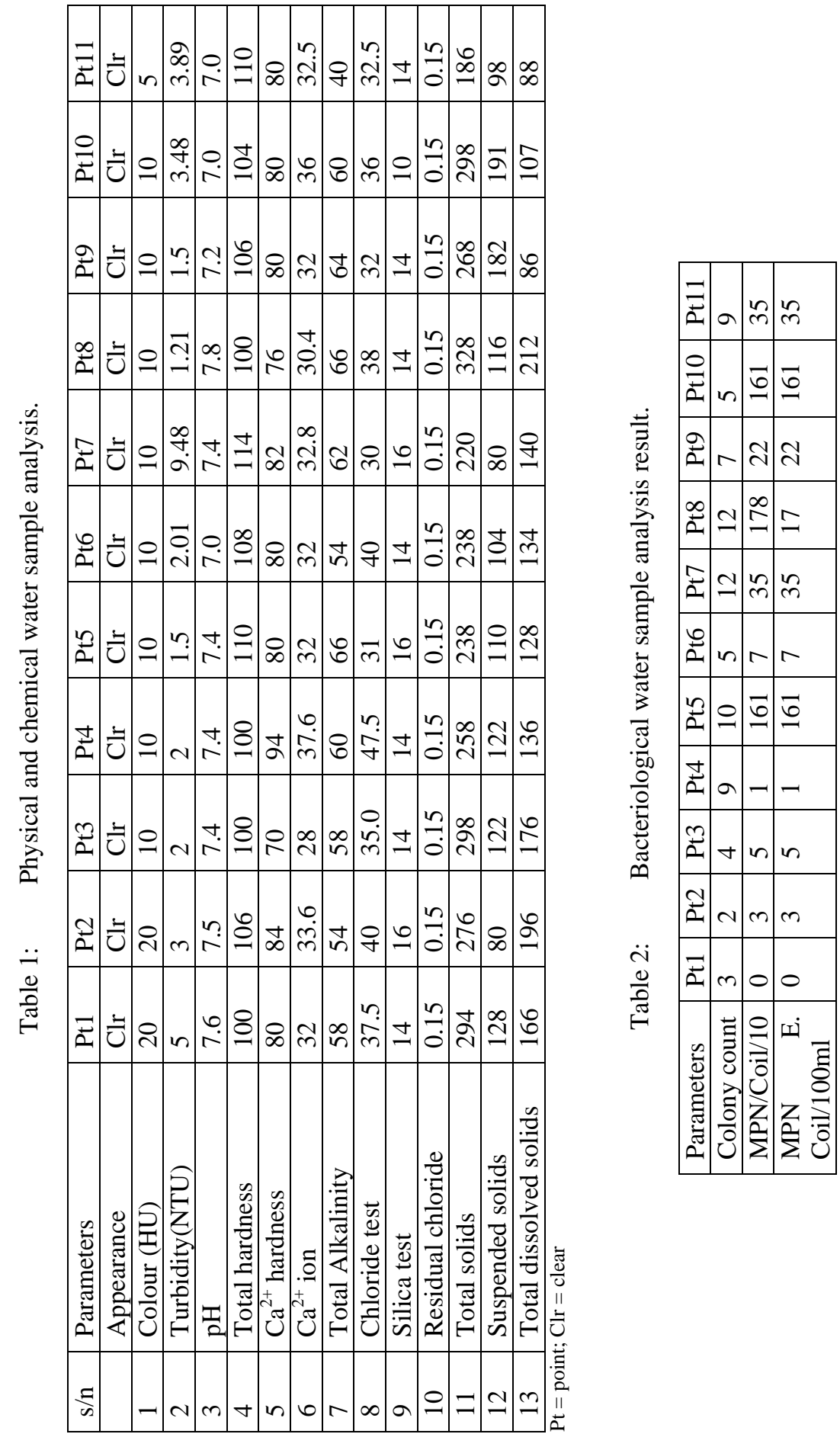




\section{Results and discussions}

In what follows are the tables containing results of water sample analysis, Table 1 showed the results of physical and chemical water sample analysis while table 2 showed the bacteriological water sample analysis result. Tables 3 and 4 showed yearly average record of physical, chemical and bacteriological quality of water from Eleyele treatment plant. Table 3 and 4 were obtained from the laboratory record department of Eleyele treatment plant.

Table 3: $\quad$ Existing record of physical and chemical analysis of Eleyele treated water.

\begin{tabular}{|l|l|l|l|l|l|}
\hline Parameters & Jan 2004 & July 2004 & Dec 2004 & July 1985 & Nov 1995 \\
\hline Appearance & Clear & 16.84 & $\begin{array}{l}\text { Clear with } \\
\text { particles }\end{array}$ & Clear & Clear \\
\hline Turbidity & 4.6 & 20 & 15 & - & 5.7 \\
\hline Colour & 5 & 6.6 & 10 & 25 & 10 \\
\hline Total hardness & 84 & 44 & 108 & 28 & 80 \\
\hline $\mathrm{Ca}^{2+}$ hardness & 64 & 86 & 86 & 72 & 50 \\
\hline $\mathrm{Ca}^{2+}$ ion & 25.6 & 58 & 34.4 & 28 & 20 \\
\hline Total alkalinity & 58 & 23.2 & 50 & 66 & - \\
\hline Chloride test & 30 & 47.5 & 33.5 & 26 & 30 \\
\hline Silica test & 16 & - & 14 & - & 15 \\
\hline $\begin{array}{l}\text { Residual } \\
\text { chloride }\end{array}$ & 0.15 & 0 & 0.125 & - & - \\
\hline Total solids & - & 8 & - & - & 202 \\
\hline $\begin{array}{l}\text { Suspended } \\
\text { solids }\end{array}$ & - & 30.9 & - & - & 202 \\
\hline $\begin{array}{l}\text { Total dissolved } \\
\text { solids }\end{array}$ & - & 139 & - & 143 & 165 \\
\hline
\end{tabular}

Source: Eleyele treatment works record department

Table 4: Existing record of bacteriological water quality of Eleyele treated water (1990).

\begin{tabular}{|l|l|}
\hline Parameters & Result/100ml \\
\hline Colony count & 0 \\
\hline MPN Coloi & 0 \\
\hline MPN E. Coli & 0 \\
\hline
\end{tabular}

Source: Eleyele treatment works record department 
Table 5: $\quad$ Various standard specification for drinking water.

\begin{tabular}{|c|c|c|c|c|c|}
\hline Parameter & Nigeria & WHO & Indian & ENDWQS & EUDWS \\
\hline Colour & $15 \mathrm{TCU}$ & $\begin{array}{l}\text { No } \\
\text { guideline }\end{array}$ & 5 & 20 & $\begin{array}{l}\text { acceptable to } \\
\text { consumers } \\
\text { and no } \\
\text { abnormal } \\
\text { change }\end{array}$ \\
\hline Turbidity & $5 \mathrm{NTU}$ & $\begin{array}{l}\text { No } \\
\text { guideline }\end{array}$ & 10 & 4 & $\begin{array}{l}\text { Not } \\
\text { mentioned }\end{array}$ \\
\hline $\mathrm{pH}$ & $\begin{array}{l}6.5- \\
8.5\end{array}$ & $6.5-6.8$ & $\begin{array}{l}6.5- \\
8.5\end{array}$ & $6.5-9.5$ & $6.5-9.5$ \\
\hline Total hardness & - & - & 300 & - & - \\
\hline $\mathrm{Ca}^{2+}$ & 150 & - & 75 & - & - \\
\hline $\begin{array}{l}\text { Total } \\
\text { alkalinity }\end{array}$ & - & - & 200 & - & - \\
\hline Chloride & 250 & 250 & 250 & 250 & 250 \\
\hline Silica & - & - & - & - & - \\
\hline $\begin{array}{l}\text { Residual } \\
\text { chloride }\end{array}$ & $\begin{array}{l}0.2- \\
0.25\end{array}$ & - & 0.2 & - & - \\
\hline $\begin{array}{l}\text { Total dissolve } \\
\text { solid }\end{array}$ & 500 & $\begin{array}{l}\text { No } \\
\text { guideline }\end{array}$ & 500 & - & $\begin{array}{l}\text { Not } \\
\text { mentioned }\end{array}$ \\
\hline E-coli & $0 / 100 \mathrm{ml}$ & $\begin{array}{l}\text { No } \\
\text { guideline }\end{array}$ & - & $0 / 100 \mathrm{ml}$ & $0 / 200 \mathrm{ml}$ \\
\hline
\end{tabular}

Nigeria: $\quad$ Nigeria Standard for Drinking Water Quality

WHO: $\quad$ World Health Organization Drinking Water Standard

Indian: Indian standard Specifications for Drinking Water

ENDWQS: European and National drinking Water Quality Standard

EUDWS: European Union's Drinking Water Standard

\subsection{Colour}

The world health organization [8] drinking water standard did not mention any guideline with respect to colour. European Union's [9] drinking water standard recommended that the quality of water intended for human consumption must be "acceptable to consumers and no abnormal change”. Indian standard for drinking 
water recommended minimum of 5 units and maximum of 15 units, Nigerian standard for drinking water quality (table 5) [10] recommended maximum of 15 units while European and National Drinking Water Quality Standards (ENDWQS) [11] recommended 20 units. However, the results showed above (Table 1) revealed that the entire sample analysed indicated 5 to 20 units which did not fall within the Nigerian and Indian standards mentioned above. The results of water sample collected at point 1 and point 2 fell out of the Nigerian and Indian standard [14].

\subsection{Turbidity}

The suspended matter causing turbidity is expected to be clay, silt, nonliving organic particles, plankton, and other microscopic organisms. It must be noted that turbidity can also be caused by precipitated calcium carbonate in hard waters, aluminum hydrate in treated water, and precipitated iron oxide in corrosive water. Since turbidity is removed by coagulation, sedimentation and filtration unexpected high readings of turbidity also can be used as an interpretation of failures in treatment plant operation. European Union's [9] drinking water standard recommended that the turbidity quality of water intended for human consumption must be "acceptable to consumers and no abnormal change”. European and National Drinking Water Quality Standards [11] recommended 4 units. Turbidity in the distribution system should be maintained under 5 and 10 units, that is the Nigerian and Indian standard respectively [13, 14]. WHO gave no guideline for turbidity of drinking water quality. The turbidity as shown in table 1 failed at points 1 and 7 to meet ENDWQS, Indian and WHO set standard.

\section{$3.3 \mathrm{pH}$}

$\mathrm{pH}$ value or hydrogen ion concentration, gives an indication of the degree of acidity of the water. $\mathrm{pH} 7$ is neutral; values below 7 indicate acidic characteristics and values greater than 7 indicate alkaline characteristics. The minimum and maximum allowable $\mathrm{pH}$ range for portability is $6.5-8.5$ (WHO1984) and 6.5-8.5 was recommended by Indian standard [14] and safe drinking water Act [12] while European and National Drinking Water Quality Standards [11] recommended 6.5-9.5. Nigerian standard for drinking water quality [13] recommended 6.5-8.8. All the samples tested fell within all the standards mentioned above.

\subsection{Hardness}

Hardness may be considered as a physical or chemical parameter of water. It represents the total concentration of calcium and magnesium ions, reported as calcium carbonate. In other words, "hard" water requires more soap to produce foam or lather. A voluminous body of literature suggests that in the United States and other developed nations, the incidence of many chronic disease but particularly cardiovascular disease (heart disease hypertension and stroke) is 
associated with various water characteristics related to hardness. European and National Drinking Water Quality Standards [11] as well as European Union's [9] drinking water standard were silence about hardness quality of drinking water, the Nigerian standard recommended maximum permissible of $150 \mathrm{mg} / \mathrm{l}$. Indian standard put its requirement desirable limit at 300mg/l. WHO [8] gave no guideline. However, the result in the table 1 above shows that the water is moderately hard and this can said to be okay as it complied with the Nigerian standard for drinking water quality [10].

\subsection{Calcium}

The WHO [8]and Indian standard recommended $75 \mathrm{mg} / 1$ as requirement desirable limit and 200mg/1 as an excessive limit. European and National Drinking Water Quality Standards [11], Nigerian standard [10] and European Union's [9] drinking water standard were all silence about calcium quality of drinking water. However, result of water sample (Table 1) in this study compared favourably with the WHO standards.

\subsection{Alkalinity}

There is no correlation between alkalinity and health in evaluation of drinking water quality parameters. Alkalinity in water is related to $\mathrm{pH}$, hardness, calcium, magnesium, sodium, potassium and sulfates, total solids-parameters usually examined in water analyses. From the potability viewpoint, alkalinity is not a significant parameter. Variations of concentration from 5 to $125 \mathrm{mg} / \mathrm{l}$ are expected. The extreme of these values are tolerated in water supplies. It is interesting to note that the results in table 1 showed that the alkalinity of the water samples is in order. It is interesting to note that European and National Drinking Water Quality Standards [11], Nigerian standard [10], WHO [8] and European Union's drinking water standard [9] were all silence about alkalinity quality of drinking water. Indian standard [14] recommended maximum permissible alkalinity of $200 \mathrm{mg} / \mathrm{l}$, all the water sample tested fell within the Indian standard (Table 1).

\subsection{Chloride}

Chloride is a component of common salt. It may occur in water naturally but it may be present due to local use of de-icing salt and saline intrusion. It is amazing to note that the European and National Drinking Water Quality Standards [11], Nigerian standard [10], WHO standard [8], European Union's drinking water standard [9] and Indian standard [14] documented chloride of an average 250 $\mathrm{mg} / \mathrm{l}$ as drinking water standard recommended for quality of water intended for human consumption. All the water samples analysed harmonise with the above standard. It is quite pertinent to mention here that chloride is the only drinking water quality parameter that all the international standards compared in this study agreed on the same value $(250 \mathrm{mg} / \mathrm{l})$. 


\subsection{Silica}

Recently it has been established that silicon is an essential nutritional trace element, confirmed only in animal studies. Essential dietary requirements have not been verified for humans. The European and National Drinking Water Quality Standards [11], Nigerian standard [10], WHO standard [8], European Union's drinking water standard [9] and Indian standard [14] were silence about silica quality of drinking water. Therefore, no standards have been issues by the Health Authorities for silicon or silica.

\subsection{Solids}

In drinking water, total dissolved solids are made up primarily by inorganic salts with small concentrations of organic matter. Contributing ions are mainly carbonate, bicarbonate, chloride, sulfate, nitrate, sodium, potassium, calcium and magnesium. Major contributions to total dissolved solids in water is the natural contact with rocks and soil with minor contribution from pollution in general. The purpose of these parameters is to evaluate and measure all suspended and dissolved matters in water. In spite of the chemical composition, solids are classified among the physical or general parameters of water quality.

Total solids content of $500 \mathrm{mg} / 1$ was recommended by Nigerian and Indian standards as desirable upper limit, beyond this palatability decreases and may cause gastro intentional irritation [14]. The European and National Drinking Water Quality Standards [11] was silence about solids quality in drinking water while the European Union's drinking water standard and WHO [8, 9] issued no guideline. However, water samples of Eleyele water works collected in all the study area competes favourably with the Nigerian and Indian standards.

\subsection{Residual chloride}

Chlorine is used extensively in the disinfections of drinking water in order to kill all the potentially harmful organisms that could constitute a risk to public health. During the process of chlorination, i.e. disinfecting using chlorine, there has to be an allowance for residual chlorine which will take care of possible contamination while the water is in the distribution network or possibly at the consumer residence. Water leaving the treatment plant or disinfections facilities may contain concentrations between $1.0-20 \mathrm{mg} / \mathrm{l}$ of free residual chlorine. Under normal circumstance, the first consumer should not receive more than $0.5 \mathrm{mg} / 1$ of free chlorine residual. The entire water samples analysed (table 1) showed residual chloride of $0.15 \mathrm{mg} / \mathrm{l}$ which is $<0.5 \mathrm{mg} / \mathrm{l}$. This result complied with Nigerian and Indian standards for drinking water quality [10, 14]. It is also pertinent to note that the existing record of physical and chemical analysis of Eleyele treated water (table 3) showed residual chloride of $0-0.125 \mathrm{mg} / \mathrm{l}$. 


\subsection{Bacteriological quality}

The result of the bacteriological test carried out in this study showed that the bacteriological quality of the water collected at the various consumer points is nothing to write home about. The result shows most probable number (MPN) Ecoli as high as $161 / 100 \mathrm{ml}$ at sample collection point 5 (Table 2) as against 0/100ml recommended by ENDWQS and WHO standards. Worse still, the bacteriological results fell out of the European Union's drinking water E-coli standard of 0 in $200 \mathrm{ml}$. The result also revealed that Eleyele treatment plant is capable of producing potable water of "No E-coli /100ml” (sample collection point 1) which meet up with the world standards. The high E-coli could be as a result incessant pipe burst or leakages. The health implications of E-coli presence in drinking water are: urinary tract infections, bacteraemia, meningitis, diarrhea (one of the main cause of morbidity and mortality among children), acute renal failure and haemolytic anaemia [13].

\section{Conclusions and recommendations}

Water companies do their utmost to produce drinking water of impeccable quality at treatment plant. The objective of the distribution network is to fulfill the legal obligation to bring water to the customers in sufficient quantities under sufficient pressure. Next to this quantitative goal is the qualitative goal of the distribution of drinking water to preserve the impeccable quality during the travel time through the network. More realistically the goal is to control deterioration of quality to meet standards for consumption.

The results of water sample tests carried out in this study showed that, despite the age of the treatment plant, it is still producing potable water that is not physically, chemically and bacteriological far from the international standards. The main problem identified in this study is the deterioration of water quality in the distribution network. The increase in deterioration or contamination within the distribution system as water moves away from the treatment plant could be as a result of the following: the breaks or leaking of the distribution pipes, the contaminated pool of water formed around the leaking pipes during the high pressure may find its way into the distribution pipes during the low pressure. Septic tank and soak away are dug everywhere within the city and sometimes near the water distribution pipes. Underground pipe leakage few meters away from soak away can serve as a source of contamination.

It is recommended that pressure test should be carried out on the pipe network with a view to detect the weak points and affect necessary maintenance. Water must be distributed in sufficient quality and pressure at all times to avoid backsiphonage. When existing water mains are repaired or replaced or when new water mains are installed strict protocols involving disinfection and flushing must be followed to prevent the introduction of contaminated soil or debris into the system. It is stating the obvious that the pipe network of Eleyele treatment plant has stayed beyond design period, thus, there is a need for complete reassessment in line with development along path of distribution. Water analysis 
alone is not sufficient to maintain quality but must be combined with the periodic review and acceptance of the facilities involved. This approval consists of the evaluation and maintenance of proper production of the water supply's adequate monitoring work and also evaluation of the quality performance of laboratory works.

\section{References}

[1] Ikelionwu, C. Water Quality Monitoring and Surveillance in Nigeriahttp://nwri.gov.ng/userfiles/file/FMWR_Water_Quality_Surveillenc e_draft.pdf.

[2] World Health Organization .Rapid Assessment of Drinking Water Quality in the FederalRepublic of Nigeria Country Report of the Pilot Project Implementation in 2004-2005 http://www.wssinfo.org/fileadmin/ user_upload/resources/RADWQ_Nigeria.pdf.

[3] Ainsworth, R. A. Water quality changes in piped distribution system. World Health Organization 2002.

[4] Craun, G.F. and Calderon, R.L. Waterborne disease outbreak caused by distribution system deficiencies, Journal of the American Water Works Association 93, 64 - 75. 2001.

[5] WaterAid International site .Testing the water in Nigeria http://www.wateraid.org/international/what_we_do/where_we_work/nigeri a/4245.asp.

[6] Clark, J. A. The Presence- Absence test for monitoring drinking water quality. In: drinking Water Microbiology. McFeters, G.A. IEd) SpringerVerlag, New York, pp399-41, 1990.

[7] Wright R. C. (1986). The seasonality of bacterial quality of water in a tropical developing country (sierra Leone). Journal of Hygiene 96(1), 7582, 1986.

WHO's drinking water standards . WHO's Guidelines for Drinking-water Quality, set up in Geneva. http://www.lenntech.com/applications/drinking/ standards/who-s-drinking-water-standards.htm.

[8] European Union's drinking water standards. Council Directive 98/83/EC on the quality of water intended for human consumption. http://www.lenntech.com/applications/drinking/standards/eu-s-drinkingwater-standards.htm.

[9] Nigerian Standard for Drinking Water Quality http://www.unicef.org/ nigeria/ng_publications_Nigerian_Standard_for_DrinkingWater_Quality.pd f.

[10] European and National Drinking Water Quality Standards http://www.doeni.gov.uk/niea/european_and_national_drinking water_quality standards - october_2011.pdf.

[11] Safe Drinking Water Act (SDWA) .http://water.epa.gov/lawsregs/rulesregs/ sdwa/index.cfm. 
186 Water Resources Management VII

[12] Nigerian Industrial Standard http://www.unicef.org/nigeria/ ng_publications_Nigerian_Standard_for_Drinking_Water_Quality.pdf.

[13] Indian standard specification for drinking water IS 10500 http://hppcb.gov.in/eiasorang/spec.pdf. 